\title{
AN INVESTIGATION OF SOME PHENOLOGICAL EVENTS IN THREE MANGROVE GENERA WITH REFERENCE TO SELECTED CLIMATIC FACTORS IN NEGOMBO LAGOON
}

\author{
P L Hettiarachchi and G W N T Kumara \\ University of Sri Jayewardenepura, Nugegoda.
}

Mangroves consist of lew tree species which are adapted to grow under tidal conditions. Studies on the phenology of mangroves is scarce. The main objective of this research was to study major phenological cycles of some overexploited species and to compare these with previous observations on the same species samples from three other lagoons.

Phenological cycles of lealing, flowering and fruiting of Rhizophora apiculara, $R$. Mucronata, Bruguiera gymmorhiza, B. Sexangula and Coriops tagal were studies for a period of 24 months at selected sites in Negombo lagoon which is located in the wet rone of Sri Linka. Phenological cycles were followed and phenological indices were calculated. These data were compared with monthly variations in rain fall, temperature and humidity of the sludy area.

Leal production showed two distinct maxima per year in all species. Rainfall seemed to excrt a great influence on leal reflushing. Peaks of leal reflushing coincided with lulls of flowering and fruiting. Annual himodality was ohserved for llowering fruiting in all species. These species showed unimodal pattern of some of these events when they were growing in dry zonc.

Phenological cycles constructed using data obtained show no intraspecific variation in the time required to complete a single flowering-fruiting cycle. Similarly, intrageneric vartiation was absent in the life time of leafing cycles.

In Rhizophora species, leaf bud jut emerged took $1-1.5$ yrs to complete a single cycle where as in Brugniera species this period was $2-2.5$ yrs. In Ceriops tagal ${ }_{2}$ it was $1.5-2$ yrs. Similarly, a flower bud of Rhizophora species took $1.5-2.5$ yrs, Brugeciera species 1 yr and $C$. lagal ahout 1.5 yrs to form a mature hypocotyl.

A comparison of these observations with lindings of the previous study proves that phenological cycles in studies species are environmentally dependent and not species specific.

Unimodality of floral phenology in dry zone species may be due to the seasonal variation in ground water salinily.

Procedings of the Fourth Ammal Forestry and Emiromment Symposium 1998 of the Department of Fore'stry and Envirommental Science, University of Sri Jaye'uardenepara, Sri Lanka 